\title{
PENGEMBANGAN PETUNJUK PRAKTIKUM HISTOLOGI PROGRAM STUDI PENDIDIKAN BIOLOGI
}

\section{DEVELOPMENT OF HISTOLOGICAL PRACTICUM INSTRUCTIONS BIOLOGICAL EDUCATION STUDY PROGRAM}

\author{
Nila Kartika Sari ${ }^{1)}$, Primadya Anantyarta ${ }^{2)}$ \\ Program Studi Pendidikan Biologi, Institut Keguruan dan Ilmu Pendidikan Budi Utomo Malang \\ Email: nilahakam@gmail.com
}

\begin{abstract}
ABSTRAK
Histologi merupakan salah satu matakuliah yang mempelajari struktur histologis penyusun organ terutama pada mamalia. Ketidaktersediaan bahan ajar berupa buku petunjuk praktikum, akan menghambat proses praktikum yang dilakukan oleh mahasiswa. Tujuan dari penelitian ini adalah untuk mengembangkan buku petunjuk praktikum histologi pertama kali sebagai salah satu bahan ajar yang dapat membantu proses pembelajaran mahasiswa program studi pendidikan biologi IKIP Budi Utomo malang. Metode dalam pengembangan buku petunjuk praktikum ini menggunakan model ADDIE yang memiliki tahap analysis, design, development, implementation dan evaluation. Pengembangan dilakukan hingga tahap ketiga yaitu development. Tahap pertama dilakukan analisis kebutuhan bahan ajar yang dilanjutkan dengan tahap desain. Hasil pengembangan buku petunjuk praktikum terlebih dahulu divalidasi oleh ahli media serta ahli materi. Hasil validasi aspek media mendapatkan nilai $99 \%$ dan aspek materi mendapatkan nilai $89,3 \%$ yang termasuk dalam kategori sangat valid, sehingga buku petunjuk praktikum histologi dapat digunakan sebagai bahan ajar dalam praktikum.
\end{abstract}

Kata kunci : Histologi, praktikum, ADDIE.

\begin{abstract}
Histology is one of the subjects that studies histological structures of organ organisms especially in mammals. The inadequacy of teaching materials in the form of practical manuals, will impede the practice of practicum by students. The purpose of this study is to develop the first histology manual as one of the instructional materials that can help the learning process of biology education students of IKIP Budi Utomo unlucky. Methods in the development of this practice manual use the ADDIE model which has the stage of analysis, design, development, implementation and evaluation. Development is done up to the third stage of development. The first step is the analysis of the material needs of the materials and the design phase. The results of the development of practical manual are validated by media experts and materials experts. Result of validation of media aspect get value of $99 \%$ and material aspect get score of $89,3 \%$ which is included in very valid category, histology practicum guide book can be used as teaching material in practice.
\end{abstract}

Keywords: Histological, practicum, ADDIE. 


\section{PENDAHULUAN}

Keberlangsungan proses pembelajaran tentu bertujuan mencapai tujuan dalam belajar. Tujuan pembelajaran dapat diwujudkan dalam suatu ranah belajar yang meliputi 3 aspek yaitu aspek kognitif (pengetahuan), aspek afektif (sikap) dan aspek psikomotorik (keterampilan). Aspek kognitif dapat terlihat dari hasil tes siswa/ pebelajar. Aspek afektif dapat dilihat dari sikap yang dilakukan siswa selama proses pembelajaran. Aspek psikomotorik dapat diketahui dari keterampilan siswa selama kegiatan praktikum (Anantyarta \& Hariyanto, 2018, p. 12). Pembelajaran dengan praktikum merupakan kegiatan yang dilaksanakan dengan memanfaatkan keterampilan dalam pengoperasian alat seperti mikroskop, mengamati objek, serta mencatat atau mendokumentasikan.

Pembelajaran di tingkat perguruan tinggi tentu memiliki level berbeda (di atas tingkat dasar \& menengah). Sebutan bagi peserta didik pun menjadi mahasiswa yang diajar oleh dosen, bukan guru. Meski terdapat perbedaan tersebut, namun tidak mengganti peran masing-masing dalam proses pembelajaran. Proses pembelajaran saat ini ditekankan pembelajaran yang berpusat pada siswa (student centered). Peran mahasiswa semakin mandiri dalam pembelajaran. Kemandirian tersebut tentu tidak dapat dilepaskan sama sekali tanpa bantuan dosen sebagai pembimbing, fasilitator, teman, bahkan sebagai orang tua dalam pembelajaran.

Terdapat berbagai unsur yang diperlukan dalam proses pembelajaran. Baik fasilitas/ sarana dan prasarana, model, metode, dan media pembelajaran merupakan beberapa unsur tersebut. Khusus pada media pembelajaran dapat dibedakan menjadi media pembelajaran bersifat audio, visual dan audio-visual. Salah satu jenis media pembelajaran minimal harus ada dalam pembelajaran untuk membantu proses mencapai tujuan dari pembelajaran itu sendiri.

Histologi merupakan salah satu cabang ilmu biologi yang mempelajari tentang struktur penyusun organ tubuh suatu makhluk hidup, terutama pada mamalia. Struktur histologi ini dapat diamati secara mikroskopis oleh mahasiswa dalam proses pembelajaran yaitu dengan kegiatan praktikum. Tanpa adanya kegiatan praktikum, tentu pengalaman langsung tidak akan didapatkan, karena histologi lebih ditekankan pada 
pembelajaran yang bersifat kontekstual. Kontekstual merupakan hal yang bersifat nyata atau ditemui dan dialami sendiri oleh mahasiswa dalam kehidupan sehari-hari.

Berdasarkan analisis kebutuhan bahan ajar pada matakuliah histologi program studi pendidikan biologi IKIP Budi Utomo Malang, diketahui bahwa belum ada buku petunjuk praktikum histologi yang digunakan untuk membantu proses pembelajaran. Berdasarkan hasil wawancara mahasiswa dan dosen pengampu, diketahui bahwa mahasiswa menginginkan adanya buku panduan yang membantu dalam kegiatan praktikum. Dosen pun menekankan bahwa sangat dibutuhkan buku petunjuk praktikum serta ketersediaan alat dan bahan dalam praktikum agar proses pembelajaran terutama praktikum dapat berlangsung dengan baik.

Buku petunjuk praktikum merupakan suatu buku panduan dalam melaksanakan kegiatan pembelajaran dalam hal praktikum yang memanfaatkan hal di sekitar sebagai sumber belajar. Konten dari buku petunjuk praktikum diharapkan meliputi proses/ kegiatan sains seperti keterampilan dalam mengamati, keterampilan menafsirkan hasil amatan, mengelompokkan, mermalkan, mengkomunikasikan, merumuskan hipotesis dan lainnya (Rustaman, dalam Meyhandoko, A., 2013).

Adanya materi perkuliahan yang kompleks tentu sangat diinginkan oleh mahasiswa untuk membantu proses pembelajaran. Terlebih lagi adanya langkah atau petunjuk dalam melaksanakan kegiatan praktikum seperti histologi sangat memudahkan bagi mahasiswa. Kesatuan antara materi dan petunjuk praktikum yang dilengkapi dengan soal latihan serta wadah untuk mendokumentasikan hasil praktikum dalam satu bahan ajar dapat diwujudkan salam suatu buku petunjuk praktikum. Buku petunjuk praktikum merupakan salah satu bahan ajar yang bersifat visual. Atas dasar tersebut peneliti beranggapan bahwa adanya buku petunjuk praktikum sebagai bahan ajar ataupun media dalam belajar dapat membantu dan mencapai tujuan pembelajaran.

\section{METODE}

\section{a. Prosedur Pengembangan}

Dalam melakukan penelitian pengembangan buku petunjuk praktikum histologi ini menganut dari model ADDIE yang dikembangkan oleh Lee, W.W. \& Owens, D.L. (2004). Terdapat 5 tahap yaitu analyze (analisis), designe (desain), 
development (mengembangkan), implementation (implementasi) dan evaluation (evaluasi).

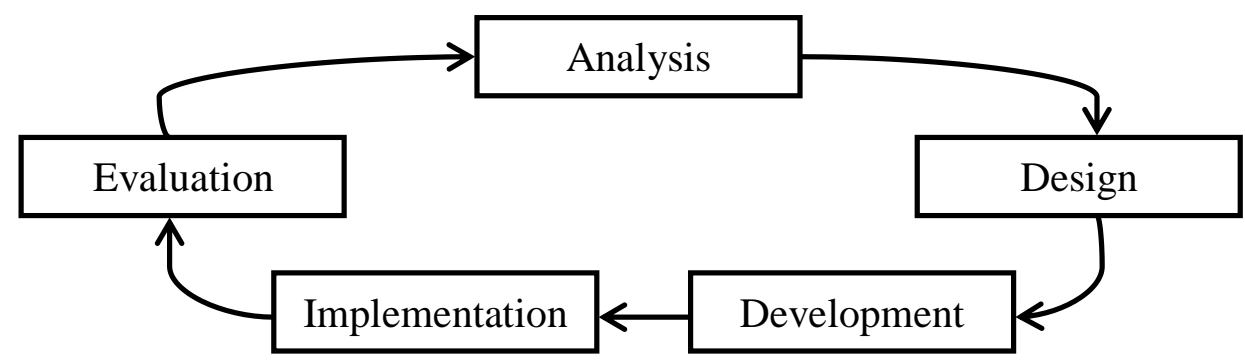

Gambar 1. Alur model pengembangan Lee, W.W. and Owes (2004) dalam Anantyarta (2017)

Batasan dalam penerapan tahap pengembangan yaitu hanya dilakukan sampai pada tahap ketiga yaitu develop (pengembangan) produk sebelum tahap implementasi pada mahasiswa serta tahap kelima yaitu evaluasi produk akhir setelah tahap uji coba. Produk dikembangkan dan dilakukan validasi oleh 2 ahli yaitu ahli materi dan ahli media pembelajaran.

\section{Analyze (analisis)}

Pada tahap pertama dilakukan analisis, yakni melakukan pendefinisian terhadap permasalahan instruksional pada perkuliahan histologi, tujuan pembelajaran serta pada sasaran pembelajaran/ kebutuhan bagi kelancaran pembelajaran. Pada penelitian ini merupakan lanjutan dari tahap analisis yang telah dilakukan yakni mengetahui kebutuhan yang didapatkan dari analisis kebutuhan mahasiswa dan dosen dalam perkuliahan histologi. Hal apa yang menjadi kekurangan dan diharapkan dapat terpenuhi dengan adanya tahap pengembangan ini.

\section{Design (desain)}

Pada tahap kedua dilakukan desain atau merancang buku petunjuk praktikum. Desain meliputi sampul buku serta konten dari petunjuk praktikum histologi ini. Pertimbangan berbagai unsur, baik nilai intrinsik serta estetik bahan ajar, maka dirancanglah suatu buku petunjuk yang berisikan materi serta langkah dan wadah untuk mendokumentasikan hasil kegiatan praktikum. Pada bagian cover menggunakan warna dasar ungu gelap serta terdapat tulisan utama berupa buku petunjuk praktikum dan nama matakuliah serta contoh gambar histologis dari suatu jaringan. Beralih pada konten atau isi buku petunjuk praktikum diawali dengan kata pengatar, tata tertib dalam praktikum, 
pendahuluan, daftar isi serta konten materi. Pada bagian isi atau konten dibagi menjadi 10 sub judul yang berisi 1) jaringan epitel, 2) Jaringan ikat, 3) jaringan otot, 4) jaringan saraf, 5) Sistem integument, 6) Sistem pencernaan, 7) sistem peredaran, 8) sistem urinaria, dan 10) sistem genetalia. Pada materi sistem pencernaan dan sistem genetalia dibagi menjadi 2 pertemuan/ praktikum karena memiliki konten yang lebih banyak dari sub bab lainnya. Terutama ada materi sistem genetalia dibagi menjadi sistem genetalia jantan dan betina.

\section{Development (Pengembangan)}

Pada tahap ketiga dilakukan pengembangan buku petunjuk praktikum ini dengan melakukan validasi terhadap tampilan secara keseluruhan oleh ahli media dan konten oleh ahli materi histologi. Rubrik peniliaian pada validasi media berisi 25 pertanyaan serta 20 pertanyaan pada validasi materi. Skor terendah 1 dan skor tertinggi 4 untuk memberikan penilaian terhadap buku petunjuk. Adanya deskripsi penilaian dari validator diharapkan dapat menambah keluwesan saran dan komentar pada pengembangan buku petunjuk praktikum ini.

Rubrik validasi media meliputi: a) ukuran buku (kesesuaian ukuran dengan standar ISO, kesesuaian ukuran dengan materi isi buku); b) Desain tata letak kulit buku (Penampilan unsur tata letak pada kulit muka, belakang dan punggung memiliki kesatuan, Menampilkan pusat pandang yang baik, Kombinasi unsur tata letak (judul, pengarang, ilustrasi), Ukuran unsur tata letak proporsional dengan ukuran buku, Warna unsur tata letak harmonis dan memperjelas fungsi (materi isi buku), Menampilkan kekontrasan yang baik); c) Tifografi/ Huruf yang digunakan menarik dan mudah dibaca (Ukuran huruf judul buku lebih dominan dibandingkan nama pengarang, Warna judul buku kontras dengan warna latar belakang, Ukuran huruf proporsional dibandingkan ukuran buku); d) Huruf yang sederhana (Tidak terlalu banyak kombinasi jenis huruf, Sesuai dengan jenis huruf untuk isi/materi); e) Ilustrasi/ mencerminkan isi buku (Ilustrasi mampu mengungkapkan karakter objek, Bentuk, warna, ukuran proporsi objek sesuai realita); f) Desain / tata letak konsisten isi buku (Penempatan tata letak konsisten berdasarkan pola, Spasi antar paragraf jelas, Penempatan judul bab dan yang setara konsisten); g) Kelengkapan unsur tata letak buku (Judul bab, Angka halaman, Keterangan gambar); h) Tifografi isi buku (Tidak menggunakan terlalu banyak jenis 
huruf, Spasi antar baris susunan teks normal, Mampu mengungkapkan makna/.arti dari objek, Keseluruhan ilustrasi serasi).

Rubrik validasi materi meliputi : a) Kesesuaian uraian materi dengan capaian pembelajaran Matakuliah (Keluasan materi, Kedalaman materi, Pemilihan tema); b) Keakuratan materi (Keakuratan fakta dan konsep, Keakuratan gambar); c) Materi pendukung praktik (Kesesuaian dengan perkembangan ilmu, Kontekstual); d) Teknik penyajian (Keruntutan konsep, Kekonsistenan sistematika penulisan, Keseimbangan antar bab); e) Penyajian pembelajaran (Berpusat pada mahasiswa (peserta didik), Keakuratan ilustrasi, Memperhatikan aspek keselamatan praktikum, Variasi penyajian); f) Kelengkapan penyajian (Kata Pengantar, Daftar isi, Daftar pustaka, Evaluasi, Proporsi gambar dan teks yang tepat, Ilustrasi yang mendukung pesan).

\section{Implementation (Implementasi)}

Tahap keempat dalam pengembangan buku petunjuk praktikum ini adalah melakukan implementasi produk. Hal ini dilakukan dengan cara menggandakan buku petunjuk praktikum dan digunakan oleh mahasiswa program studi pendidikan biologi IKIP Budi Utomo Malang. Harapan dari dengan dilaksanakan implementasi pada mahasiswa secara langsung adalah mengetahui kebermanfaatan serta kekurangan yang masih terdapat pada buku petunjuk praktikum. Hal yang didapatkan dari implementasi selama pembelajaran dengan menggunakan buku petunjuk praktikum ini akan diperbaiki terlebih dahulu pada tahap pengembangan selanjutnya.

\section{Evaluation (Evaluasi)}

tahap kelima atau tahap terakhir dari pengembangan buku petunjuk paktikum histologi adalah melakukan evaluasi atas kelebihan dan kelelmahan yang terdapat pada buku petunjuk praktikum. Kelebihan dan kelemahan buku petunjuk praktikum didapatkan dari pendapat mahasiswa sebagai subjek pengguna buku petunjuk praktikum. Data dapat berupa deskriptif serta angka persentase (\%) yang akan dilakukan setelah tahap pengembangan.

\section{b. Teknik analisis data}

Teknik yang digunakan dalam menganalisis data yang didapatkan dari hasil validasi oleh 2 ahli yaitu ahli media dan ahli materi dengan perhitungan rata-rata dan 
persentase. Validasi bertujuan untuk mengukur kelayakan suatu bahan/ media pembelajaran yang dikembangkan melalui instrumen. Instrumen yang baik merupakan instrumen yang mampu mengukur apa yang seharusnya dan dapat mengungkapkan data yang diteliti secara tepat (Arikunto, S., 2013). Instrumen berupa angket skala bertingkat yang terdiri dari 4 kategori pilihan yaitu :

Angka 4 : sangat baik

Angka 3 : baik

Angka 2 : kurang baik

Angka 1 : sangat kurang baik (Sugiono, 2011)

Analisis data hasil dari penilaian atau validasi oleh ahli media dan materi dengan menggunakan rumus menghitung rata-rata (Arikunto, S., 2013) serta diwujudkan dalam bentuk persentase (Riduwan \& Sunarto, 2013) yang menunjukkan kategori/ tingkat kevalidan bahan ajar yang dikembangkan.

1. Perhitungan Rata-rata

Dihitung dengan rumus sebagai berikut :

$$
x=\frac{\sum x}{\sum \mathrm{n}}
$$

Keterangan :

$X \quad$ : Nilai rata-rata

$\sum x \quad$ : Jumlah skor jawaban validator

$\sum \mathrm{n}:$ Jumlah indikator

2. Perhitungan persentase (\%)

Dihitung dengan rumus sebagai berikut :

$$
\mathrm{Q}=\frac{\mathrm{y}}{\mathrm{N}} \times 100 \%
$$

Keterangan :

Q : Persentase

$\mathrm{y}:$ Jumlah skor jawaban validator

$\mathrm{n}:$ Jumlah nilai indikator 
Untuk menafsirkan hasil validasi oleh ahli media dan materi, nilai yang didapatkan berupa persentase serta dihubungkan dengan skor interval pada tabel 1 berikut.

Tabel 1. Kriteria Penilaian Kevalidan (Prayitno, T.A., 2017)

\begin{tabular}{cc}
\hline Skala Nilai (100\%) & Keterangan \\
\hline $81-100$ & Sangat valid (Tidak Revisi) \\
$61-80$ & Valid (Tidak Revisi) \\
$41-60$ & Cukup Valid (Revisi) \\
$21-40$ & Kurang Valid (Revisi) \\
$0-20$ & Sangat Tidak Valid (Revisi) \\
\hline
\end{tabular}

\section{HASIL DAN PEMBAHASAN}

Hasil dari penelitian diurutkan sesuai langkah pengembanngan pada buku petunjuk praktikum histologi yaitu :

\section{Analisis}

Pada tahap ini didapatkan informasi bahwa belum adanya buku petunjuk praktikum secara khusus pada perkuliahan histologi sehingga mahasiswa mengalami kesulitan dalam melaksanakan kegiatan perkuliahan, yaitu pengamatan pada preparat histologi suatu jaringan. Buku petunjuk praktikum selain sebagai bahan ajar juga berperan sebagai sarana kelengkapan dalam proses belajar. Kurangnya unsur sarana dikhawatirkan akan berpengaruh terhadap hasil belajar yang tidak maksimal. Puspitasari, W.D., (2016) menyatakan bahwa sarana belajar akan mempengaruhi perkembangan belajar anak. Belajar jika tanpa dibantu fasilitas akan mendapatkan hambatan dalam menyelesaikan kegiatan belajarnya.

Dalam pengamatan mahasiswa sering meminta bantuan dosen sehingga satu persatu meja kelompok didatangi untuk membantu pengamatan. Alat dan bahan yang tidak memadahi seperti jumlah mikroskop yang kurang serta banyak preparat histologi yang hilang menjadi kekurangan dalam praktikum histologi. Hal ini berpengaruh terhadap hasil belajar mahasiswa mengingat histologipun merupakan hal baru dan bersifat abstrak bagi mahasiswa. Tidak jarang dosen selalu memberikan penjelasan yang 
berulang dengan menggunakan media power point untuk menekankan dan mengingatkan kembali hal penting berkaitan dengan praktikum histologi.

Mahasiswa juga memerlukan latihan menggunakan mikroskop dengan baik agar dalam pelaksanaan praktikum dapat meminimalisir waktu terbuang. Hal senada diungkapkan oleh Junitha, dkk (2013) bahwa penggunaan mikroskop merupakan salah satu keterampilan yang sangat penting karena dapat membantu meningkatkan kemampuan dalam mengamati dengan alat dibandingkan dengan mata telanjang.

\section{Desain}

Hasil dari penelitian pengembangan buku petunjuk praktikum histologi meliputi hasil berupa produk dengan hasil validasi oleh ahli media pembelajaran serta hasil validasi oleh ahli materi histologi. Pada produk menampilkan pada bagian kulit muka,kulit punggung dan kulit belakang buku. Pada kulit muka buku berwarna ungu gelap dengan judul utama berwarna putih dan hijau, menggunakanhuruf kapital, serta terletak pada bagian atas. Ditambahkan dengan tiga contoh histologis dari jaringan yang terdapat dalam praktikum histologi, diikuti dengan identitas penulis pada bagian bawah yang terletak di tengah. Pada kulit punggung dengan warna dasar ungu muda berisi judul buku serta identitas penulis yang tertulis secara vertikal. Pada kulit belakang buku juga menggunakan warna dasar ungu dengan judul serta identitas penulis seperti halaman depan disertai ringkasan dari seluruh konten praktikum histologi.

Susunan pada kulit muka buku dimaksudkan agar mahasiswa terfokus dan memahami isi dari buku petunjuk praktikum meskipun dengan sekilas mengamati kulit muka. Hal senada diungkapkan Wibawa, M. (2014) bahwa susunan sistem tanda visual yang terdapat pada sampul menggunakan tanda ikonis yang secara fisik mudah dikenali sebagai bagian dalam substansi pembelajaran. Dengan memperhatikan ilustrasi tersebut mahasiswa akan secara langsung mentautkannya dengan matakuliah terkait. Hal ini terjadi karena ikon imagis yang mudah dipahami merupakan pintu masuk pemahaman akan makna yang mudah diingat. Secara umum aspek bentuk (form) dalam sudut pandang komunikasi visual lebih diutamakan karena dengan penggunaan bahasa visual bertujuan agar suatu pesan tersampaikan. Berikut tampilan kulit buku petunjuk praktikum histologi. 


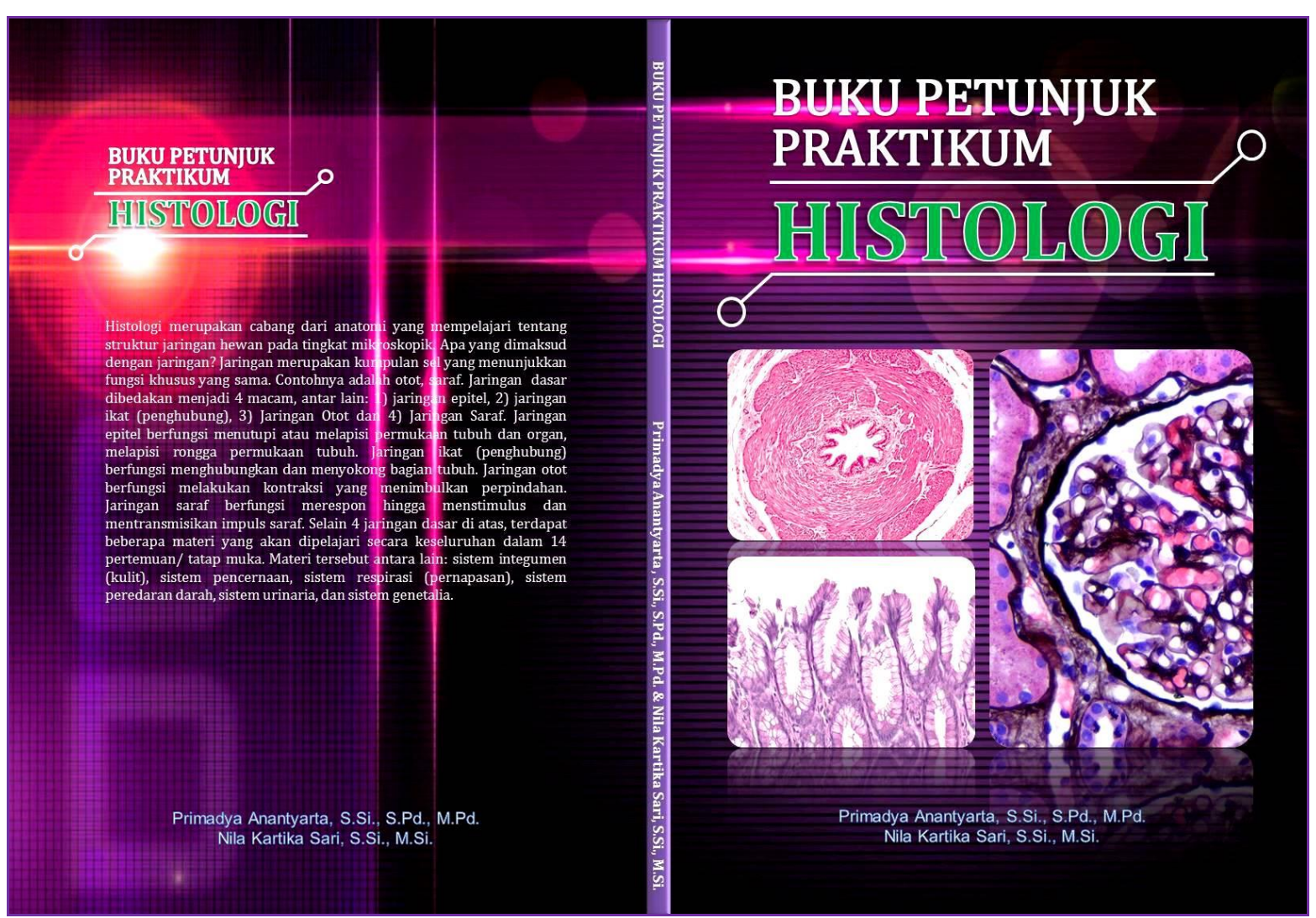

Gambar 2. Desain kulit buku petunjuk praktikum histologi hasil pengembangan

3. Pengembangan

Dalam mengembangkan buku petunjuk praktikum histologi sangat diperlukan penilaian atau validasi oleh ahli yaitu ahli media serta ahli materi. Secara deskriptif berikut hasil dari penilaian oleh para validator tersebut.

\section{a. Hasil dan Analisis Validasi oleh ahli Media Pembelajaran}

Validasi pertama oleh ahli media pembelajaran, yaitu bertujuan untuk memperoleh penliaian serta masukan/ tambahan dan saran terhadap ketepatan desain buku serta ketepatan penyusunan konten buku petunjuk praktikum histologi. Secara ringkas aspek penilaian oleh validator diringkas ke dalam 8 aspek. Untuk 7 aspek penilaian mendapatkan persentase penilaian $100 \%$ oleh validator. Aspek tersebut antara lain a) ukuran buku, b) Desain (tata letak) kulit buku, d) Huruf yang sederhana, e) Ilustrasi/ mencerminkan isi buku, f) Desain / tata letak konsisten isi buku, g) Kelengkapan unsur tata letak buku dan h) Tifografi isi buku. Sedangkan pada aspek c) Tifografi/ Huruf yang digunakan menarik dan mudah dibaca, mendapatkan persentase 
nilai sebesar $92 \%$. Saran dari validator media adalah perbaikan warna pada judul buku agar lebih terlihat tajam dari pada background. Aspek penilaian tersebut menunjukkan bahwa buku petunjuk praktikum memperoleh kriteria sangat valid.

Lebih detil, deskripsi hasil penilaian oleh validator media pembelajaran tertuang pada tabel 2 berikut.

Tabel 2. Ringkasan hasil validasi buku petunjuk praktikum histologi oleh ahli media pembelajaran

\begin{tabular}{|c|c|c|c|c|c|c|}
\hline No. & Aspek Penilaian & $\begin{array}{c}\sum \\
\text { indikator }\end{array}$ & $\begin{array}{c}\text { Skor } \\
\text { maksimal }\end{array}$ & $\begin{array}{c}\text { skor } \\
\text { validasi }\end{array}$ & Persentase & Kriteria \\
\hline 1 & Ukuran Buku & 2 & 8 & 8 & 100 & SV \\
\hline 2 & $\begin{array}{l}\text { Desain (tata letak) } \\
\text { kulit buku }\end{array}$ & 6 & 24 & 24 & 100 & SV \\
\hline 3 & $\begin{array}{l}\text { Tifografi/ Huruf } \\
\text { yang digunakan } \\
\text { menarik dan mudah } \\
\text { dibaca }\end{array}$ & 3 & 12 & 11 & 92 & SV \\
\hline 4 & $\begin{array}{l}\text { Huruf yang } \\
\text { sederhana }\end{array}$ & 2 & 8 & 8 & 100 & SV \\
\hline 5 & $\begin{array}{l}\text { Ilustrasi/ } \\
\text { mencerminkan isi } \\
\text { buku }\end{array}$ & 2 & 8 & 8 & 100 & SV \\
\hline 6 & $\begin{array}{l}\text { Desain / tata letak } \\
\text { konsisten isi buku }\end{array}$ & 3 & 12 & 12 & 100 & SV \\
\hline 7 & $\begin{array}{l}\text { Kelengkapan unsur } \\
\text { tata letak buku }\end{array}$ & 3 & 12 & 12 & 100 & SV \\
\hline 8 & Tifografi isi buku & 4 & 16 & 16 & 100 & SV \\
\hline & Jumlah & 25 & 100 & 99 & 792 & \\
\hline & Rata-rata & & 4 & 3.96 & 99 & \\
\hline
\end{tabular}

\section{Keterangan :}

SV : Sangat Valid 


\section{b. Hasil dan Analisis Validasi oleh ahli Materi Histologi}

Validasi kedua oleh ahli materi histologi, yaitu bertujuan untuk memperoleh penliaian serta masukan/ tambahan dan saran terhadap ketepatan isi atau konten, keluasan dan kedalaman materi dari histologi. Secara ringkas aspek penilaian oleh validator diringkas ke dalam 6 aspek. Untuk aspek a) Kesesuaian uraian materi dengan capaian pembelajaran matakuliah, mendapatkan persentase penilaian sebesar $92 \%$ dan termasuk kriteria sangat valid. Pada aspek b) keakuratan materi dan aspek d) teknik penyajian mendapatkan persentase penilaian sebesar $100 \%$ dan termasuk kriteria sangat valid. Pada aspek c) materi pendukung praktik mendapatkan persentase penilaian sebesar $62,5 \%$ namun masih termasuk kriteria valid dan perlu melakukakn revisi. Pada aspek e) penyajian pembelajaran mendapatkan perseentase penilaian sebesar $94 \%$ dan pada aspek f) kelengkapan penyajian mendapatkan persentase penilaian sebesar $87,5 \%$ dan kedua aspek terakhir termasuk dalam kriteria sangat valid.

Tambahan dari validator ahmi materi histologi antara lain : a) kalimat pada tata tertib diperjelas lagi mengenai penggunaan mikroskop agar mahasiswa memahami, b) pada bab jaringan epitel atau lainnya, penulisan konten disejajarkan yaitu sama-sama diberikan penjelasan dari istilah serta diberi gambar beserta keterangan yang lebih detil agar memudahkan mahasiswa dalam praktikum, c) pada tabel kosong diberikan kalimat "Nama preparat :" di dalam kolom sebagai pengantar, d) pada komponen alat dan bahan dilengkapi atau disamakan dengan tiap pertemuan yang menggunakan alat yang sama., e) ditambahkan materi yang seharusnya ada tetapi belum tertuang pada buku petunjuk praktikum seperti contoh oogenesis dan spermatogenesis pada bab sistem genetalia.

Ahmadi, U.F., (2015) mengungkapkan bahwa konten dari buku yaitu berisi pengetahuan yang harus dikuasai mahasiswa, up to date dengan perkembangan ilmu pengetahuan dan teknologi, sesuai dengan jenjang dan sasaran, bebas politis, berhubungan erat dengan pelajaran lainnya, dapat menstimuli aktivitas pribadi mahasiswa, hindari konsep yang samar, buku harus mampu memberi pemantapan, uraian teratur sesuai urutantiap bab, saling memperkuat, mengacu pada aspek kognitif, afektif dan psikomotorik, serta menggunakan bahasa ilmiah dan formal. Lebih detil, deskripsi hasil penilaian oleh validator materihistologi tertuang pada tabel 3 berikut. 
Tabel 3. Ringkasan hasil validasi buku petunjuk praktikum histologi oleh ahli materi histologi

\begin{tabular}{llccccc}
\hline No. & \multicolumn{1}{c}{ Aspek Penilaian } & $\begin{array}{c}\sum \\
\text { indikator }\end{array}$ & $\begin{array}{c}\text { Skor } \\
\text { maksimal }\end{array}$ & $\begin{array}{c}\text { skor } \\
\text { validasi }\end{array}$ & Persentase & Kriteria \\
\hline 1 & $\begin{array}{l}\text { Kesesuaian uraian } \\
\text { materi dengan capaian } \\
\text { pembelajaran } \\
\text { Matakuliah }\end{array}$ & 3 & 12 & 11 & 92 & SV \\
\hline 2 & Keakuratan materi & 2 & 8 & 8 & 100 & SV \\
\hline 3 & Materi pendukung & 2 & 8 & 5 & 62.5 & V \\
& praktik & & & & & \\
\hline 4 & Teknik penyajian & 3 & 12 & 12 & 100 & SV \\
\hline 5 & Penyajian pembelajaran & 4 & 16 & 15 & 94 & SV \\
\hline 6 & Kelengkapan penyajian & 6 & 24 & 21 & 87.5 & SV \\
\hline & Jumlah & 20 & 80 & 99 & 536 & \\
\hline & Rata-rata & & 4 & 3.96 & 89.3 & \\
\hline & & & & & & \\
\hline
\end{tabular}

\section{Keterangan :}

SV : Sangat Valid

$\mathrm{V}:$ Valid

\section{KESIMPULAN DAN SARAN}

Pengembangan bahan ajar berupa buku petunjuk prakiktum histologi yang pertama kali bagi mahasiswa program studi pendidikan biologi IKIP Budi Utomo Malang ini dapat dikatakan termasuk kriteria sangat valid. Saran dalam penelitian pengembangan ini agar disiapkan dan dikerjakan dalam waktu yang lama dalam penyusunannya. Sumber gambar yang digunakan sebagai referensi juga valid/ terpercaya serta memiliki ketajaman yang jelas agar mahasiswa mudah dalam 
menggunakannya. Adanya teori pembelajaran dalam buku petunjuk juga membantu mahasiswa mengingat kembali materi yang berkaitan dengan pokok bahasan yang sedang dikerjakan saat praktikum.

\section{DAFTAR PUSTAKA}

Ahmadi, U. F. 2015. Motivasi dan Strategi Menulis Buku. FKM Universitas Indonesia. Anantyarta, P., \& Sari, R. L. I. (2018, Februari). Pengembangan Media Auto Play dengan Metode Means Ends Analysis (MEA) pada Matakuliah Genetika. In Seminar Nasional Pendidikan IPA 2017 (Vol. 2).

Anantyarta, P., \& Hariyanto. (2018). PENGEMBANGAN PETUNJUK PRAKTIKUM PROTISTA KELAS X SMA MA'ARIF NU PANDAAN. Bioma: Jurnal Biologi dan Pembelajaran Biologi, 3(1).

Arikunto, S. (2013). Prosedur Penelitian Suatu Pendekatan Praktik. Jakarta. Rineka Cipta.

Junitha, dkk., 2013. Petunjuk Praktikum Biologi Umum. Prodi Biologi, FMIPA: Universitas Udayana.

Lee, W.W., \& Owens, D.L., 2004. Multimedia-based instructional design: computerbased trainning, web-based training, distance broadcast training, performancebased solutions (2 ${ }^{\text {nd }}$ ed.), (San Francisco: Pfeiffer).

Meyhandoko, A. (2013). Pengembangan Petunjuk Praktikum Kontekstual Dengan Pemanfaatan Kondisi Lingkungan Lokal Dalam Pembelajaran Materi Pencemaran Di SMAN 2 Rembang. Skripsi. Universitas Negeri Semarang.

Puspitasari, W.D. 2016. Pengaruh Sarana Belajar terhadap prestasi Belajar Ilmu Pengetahuan Sosial di Sekolah Dasar. Jurnal CAKRAWALA Pendas 2(2).

Prayitno, T.A. (2017). Pengembangan Buku Petunjuk Praktikum Mikrobiologi Program Studi Pendidikan Biologi. Biota, III(1):31-37.

Riduwan \& Sunarto. (2013). Pengantar Statistika untuk Penelitian: Pendidikan, Sosial, Ekonomi Komunikasi, dan Bisnis. Bandung. Alfabeta.

Sugiono. (2011). Metode Penelitian Pendidikan (Pendekatan Kuantitatif, Kualitatif, dan $R \& D)$. Bandung. Alfabeta. 
Wibawa, M. 2014. Analisis Kualitas Desain Sampul Buku Sekolah Elektronik (BSE) Mata Pelajaran Seni Budaya, Program Studi Pendidikan Seni Budaya Pascasarjana UNESA. 